\title{
Amphidinolactone B, a New 26-Membered Macrolide from Dinoflagellate Amphidinium sp.
}

\author{
Yohei Takahashi, Takaaki Kubota, Jun'ichi Kobayashi
}

Received: April 6, 2007 / Accepted: June 5, 2007

(C) Japan Antibiotics Research Association

\begin{abstract}
A new 26-membered macrolide, amphidinolactone $B$, has been isolated from a marine dinoflagellate Amphidinium sp., and the structure and relative stereochemistry were elucidated on the basis of spectroscopic data. Amphidinolactone B (1) showed modest cytotoxicity.
\end{abstract}

Keywords dinoflagellate, Amphidinium, 26-membered macrolide, amphidinolactone $\mathrm{B}$

\section{Introduction}

Marine dinoflagellates of the genus Amphidinium have been recognized as a source of novel secondary metabolites with interesting structures and bioactivities [1 4]. In our continuing search for bioactive metabolites from Okinawan marine organisms, we have investigated extracts of laboratory cultured dinoflagellates Amphidinium sp., which were symbionts of the Okinawan marine acoel flatworms

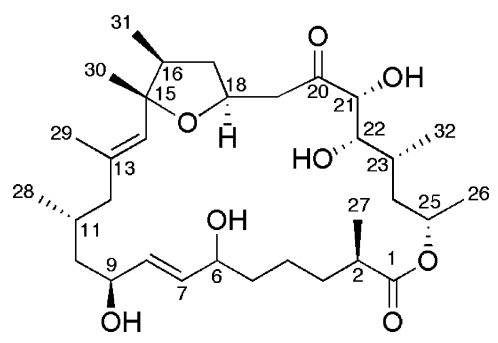

Amphidinolactone B (1)

J. Kobayashi (Corresponding author), Y. Takahashi, T. Kubota: Graduate School of Pharmaceutical Sciences, Hokkaido University, Sapporo 060-0812, Japan,

E-mail: jkobay@pharm.hokudai.ac.jp
Amphiscolops sp., and isolated a series of cytotoxic macrolides, amphidinolides, as well as long chain polyhydroxy polyketides [1]. Here we describe the isolation and structure elucidation of a new 26-membered macrolide, amphidinolactone B (1), from a strain (Y-25) of the dinoflagellate Amphidinium sp.

\section{Experimental}

\section{General}

IR and UV spectra were recorded on a Shimadzu UV1600PC and a JASCO FT/IR-5300 spectrophotometers, respectively. ${ }^{1} \mathrm{H}-,{ }^{13} \mathrm{C}$ - and $2 \mathrm{D}$ NMR spectra were measured on a Bruker AMX-600 spectrometer using $2.5 \mathrm{~mm}$ micro cells for $\mathrm{C}_{6} \mathrm{D}_{6}$ (Shigemi Co., Ltd.). Positive-mode ESI-MS were obtained on a JEOL JMS 700-TZ spectrometer using a sample dissolved in $\mathrm{MeOH}$.

\section{Cultivation and Isolation}

The dinoflagellate was unialgally cultured at $25^{\circ} \mathrm{C}$ for 2 weeks in a seawater medium enriched with $1.0 \%$ Provasoli's Erd-Schreiber (ES) [5] supplement. The harvested cells of the cultured dinoflagellate $(713 \mathrm{~g}$, wet weight, from 3000 liters of culture) were extracted with $\mathrm{MeOH} /$ toluene $(3: 1)$. After addition of $1 \mathrm{M} \mathrm{NaCl}$, the mixture was extracted with toluene. The toluene-soluble fraction was evaporated under reduced pressure to give a residue $(1.13 \mathrm{~g})$, which was subjected to a silica gel column $\left(\mathrm{CHCl}_{3} / \mathrm{MeOH}, 1: 0 \rightarrow 0: 1\right)$ and a Sep-Pak $\mathrm{C}_{18}$ cartridge $\left(\mathrm{CH}_{3} \mathrm{CN} / \mathrm{H}_{2} \mathrm{O}, 7: 3\right)$ followed by $\mathrm{C}_{18}$ HPLC [YMC Pack Pro $\mathrm{C}_{18}, 5 \mu \mathrm{m}$, YMC Co., Ltd., $10 \mathrm{~mm} \times 250 \mathrm{~mm}$; eluent, $\mathrm{MeOH} / \mathrm{H}_{2} \mathrm{O}, 80: 20$; flow rate, $2.0 \mathrm{ml} /$ minute; UV detection at $210 \mathrm{~nm}$ ] to afford $1,(80 \mu \mathrm{g}, 0.000011 \%$, wet weight $)$. 
Amphidinolactone B (1)

Colorless amorphous solid; IR $v_{\max }$ (neat) $\mathrm{cm}^{-1} 3360$ and 1720; ESI-MS $m / z 589(\mathrm{M}+\mathrm{Na})^{+}$; HRESI-MS $(\mathrm{m} / \mathrm{z}$

Table $1{ }^{1} \mathrm{H}$ - and ${ }^{13} \mathrm{C}$-NMR data of amphidinolactone B (1) in $\mathrm{C}_{6} \mathrm{D}_{6}$

\begin{tabular}{|c|c|c|}
\hline No & $\delta_{\mathrm{H}}$ & $\delta_{\mathrm{C}}$ \\
\hline 1 & & $175.6 \mathrm{~s}$ \\
\hline 2 & $2.48(1 \mathrm{H}, \mathrm{m})$ & $41.7 d$ \\
\hline 3а & $1.85(1 \mathrm{H}, \mathrm{m})$ & $35.4 \mathrm{t}$ \\
\hline $3 b$ & $1.35(1 \mathrm{H}, \mathrm{m})$ & \\
\hline $4 a$ & $1.60(1 \mathrm{H}, \mathrm{m})$ & $24.5 t$ \\
\hline $4 b$ & $1.40(1 \mathrm{H}, \mathrm{m})$ & \\
\hline 5 & $1.55(2 \mathrm{H}, \mathrm{m})$ & $38.2 \mathrm{t}$ \\
\hline 6 & $4.03(1 \mathrm{H}, \mathrm{dd}, 12.8,5.3)$ & $72.5 \mathrm{~d}$ \\
\hline 7 & $5.74(1 \mathrm{H}, \mathrm{dd}, 15.4,5.3)$ & $134.1 d$ \\
\hline 8 & $5.71(1 \mathrm{H}, \mathrm{dd}, 15.4,5.1)$ & $134.1 \mathrm{~d}$ \\
\hline 9 & $4.16(1 \mathrm{H}, \mathrm{m})$ & $70.1 \mathrm{~d}$ \\
\hline $10 a$ & $1.60(1 \mathrm{H}, \mathrm{m})$ & $43.4 \mathrm{t}$ \\
\hline $10 b$ & $1.18(1 \mathrm{H}, \mathrm{m})$ & \\
\hline 11 & $1.97(1 \mathrm{H}, \mathrm{m})$ & $28.7 d$ \\
\hline $12 a$ & $1.97(1 \mathrm{H}, \mathrm{m})$ & $49.5 t$ \\
\hline $12 b$ & $1.75(1 \mathrm{H}, \mathrm{m})$ & \\
\hline 13 & & $137.5 \mathrm{~s}$ \\
\hline 14 & $5.18(1 \mathrm{H}, \mathrm{s})$ & $131.9 d$ \\
\hline 15 & & $85.2 \mathrm{~s}$ \\
\hline 16 & $1.97(1 \mathrm{H}, \mathrm{m})$ & $43.8 \mathrm{~d}$ \\
\hline $17 a$ & $1.75(1 \mathrm{H}, \mathrm{m})$ & $40.6 \mathrm{t}$ \\
\hline $17 b$ & $1.05(1 \mathrm{H}, \mathrm{ddd}, 12.1,9.8,9.8)$ & \\
\hline 18 & $4.31(1 \mathrm{H}, \mathrm{m})$ & $74.3 \mathrm{~d}$ \\
\hline $19 a$ & $2.54(1 \mathrm{H}, \mathrm{dd}, 13.6,9.0)$ & $45.6 t$ \\
\hline $19 b$ & $2.23(1 \mathrm{H}, \mathrm{dd}, 13.6,3.6)$ & \\
\hline 20 & & $208^{\mathrm{a}} \mathrm{s}$ \\
\hline 21 & $4.15(1 \mathrm{H}, \mathrm{d}, 1.3)^{\mathrm{b}}$ & $79.2 \mathrm{~d}$ \\
\hline 22 & $3.75(1 \mathrm{H}, \mathrm{dd}, 8.8,1.3)^{\mathrm{b}}$ & $75.2 d$ \\
\hline 23 & $2.11(1 \mathrm{H}, \mathrm{m})$ & $33.3 d$ \\
\hline $24 a$ & $1.97(1 \mathrm{H}, \mathrm{m})$ & $40.6 \mathrm{t}$ \\
\hline $24 b$ & $1.12(1 \mathrm{H}, \mathrm{m})$ & \\
\hline 25 & $5.29(1 \mathrm{H}, \mathrm{m})$ & $68.3 d$ \\
\hline 26 & $1.21(3 \mathrm{H}, \mathrm{d}, 6.1)$ & $21.3 q$ \\
\hline 27 & $1.17(3 \mathrm{H}, \mathrm{d}, 7.2)$ & $17.5 q$ \\
\hline 28 & $1.00(3 \mathrm{H}, \mathrm{d}, 6.1)$ & $21.3 q$ \\
\hline 29 & $1.75(3 \mathrm{H}, \mathrm{s})$ & $18.5 \mathrm{q}$ \\
\hline 30 & $1.12(3 \mathrm{H}, \mathrm{s})$ & $23.7 \mathrm{q}$ \\
\hline 31 & $0.77(3 \mathrm{H}, \mathrm{d}, 7.0)$ & $15.5 q$ \\
\hline 32 & $1.18(3 \mathrm{H}, \mathrm{d}, 7.0)$ & $17.5 \mathrm{q}$ \\
\hline
\end{tabular}

${ }^{a}$ calculated value. The ${ }^{13} \mathrm{C}$ chemical shift of C-20 in $\mathbf{1}$ obtained from ChemNMR ver 10.0 (CambridgeSoft) was 208 ppm. Actually, those of the corresponding carbons in amphidinolide B-type macrolides are observed in the range of $210 \sim 215 \mathrm{ppm}$ [1]. ${ }^{\mathrm{b}} \mathrm{J}_{\mathrm{H} / \mathrm{H}}$ values observed in $\mathrm{CDCl}_{3}$.
$589.3712\left[(\mathrm{M}+\mathrm{Na})^{+}\right.$; calcd for $\left.\left.\mathrm{C}_{32} \mathrm{H}_{54} \mathrm{O}_{8} \mathrm{Na}, 589.3716\right]\right)$. ${ }^{1} \mathrm{H}$ - and ${ }^{13} \mathrm{C}$-NMR data see Table 1 .

\section{Results and Discussion}

The dinoflagellate Amphidinium sp. (strain number Y-25) was isolated from inside cells of the marine acoel flatworm Amphiscolops breviviridis collected off Sunabe, Okinawa. The harvested cells of the cultured dinoflagellate were extracted with $\mathrm{MeOH} /$ toluene $(3: 1)$, and after addition of $1 \mathrm{M} \mathrm{NaCl}$, the mixture was extracted with toluene. The toluene-soluble fraction was evaporated under reduced pressure to give a residue, which was subjected to a silica gel column and a Sep-Pak $\mathrm{C}_{18}$ cartridge followed by $\mathrm{C}_{18}$ HPLC to afford $1,80 \mu \mathrm{g}, 0.000011 \%$, wet weight).

1 had the molecular formula of $\mathrm{C}_{32} \mathrm{H}_{54} \mathrm{O}_{8}$ as revealed by HRESI-MS $\left[\mathrm{m} / \mathrm{z} 589.3712(\mathrm{M}+\mathrm{Na})^{+},-0.4 \mathrm{mmu}\right]$. IR absorptions at 3370 and $1720 \mathrm{~cm}^{-1}$ indicated the presence of hydroxy and carbonyl functionalities. ${ }^{1} \mathrm{H}$ - and ${ }^{13} \mathrm{C}-\mathrm{NMR}$ data (Table 1) of $\mathbf{1}$ disclosed the presence of one ester carbonyl, one $s p^{2}$ quaternary carbon, one $s p^{3}$ oxygenated quaternary carbon, three $s p^{2}$ methines, ten $s p^{3}$ methines (six of which were bearing an oxygen atom), eight $s p^{3}$ methylenes, and seven methyl groups. Considering the molecular formula, the existence of a keto carbonyl was indicated [6]. Since four out of six unsaturations were accounted for, $\mathbf{1}$ was inferred to contain two rings. Detailed analyses of the ${ }^{1} \mathrm{H}-{ }^{1} \mathrm{H}$ COSY and TOCSY spectra of $\mathbf{1}$ revealed connectivities of three partial structures, a (C-2 to C-12, C-2 to C-27, and C-11 to C-28), b (C-16 to C-19 and $\mathrm{C}-16$ to $\mathrm{C}-31)$, and $\mathbf{c}(\mathrm{C}-21$ to $\mathrm{C}-26$ and $\mathrm{C}-23$ to $\mathrm{C}-32)$ as shown in Fig. 1. HMBC correlations of $\mathrm{H}_{3}-27\left(\delta_{\mathrm{H}} 1.17\right)$ to $\mathrm{C}-1\left(\delta_{\mathrm{C}} 175.6\right)$ and $\mathrm{C}-2\left(\delta_{\mathrm{C}} 41.7\right)$ indicated connectivities of $\mathrm{C}-1$ to $\mathrm{C}-2$ and $\mathrm{C}-2$ to $\mathrm{C}-27$. Connections between $\mathrm{C}-12$
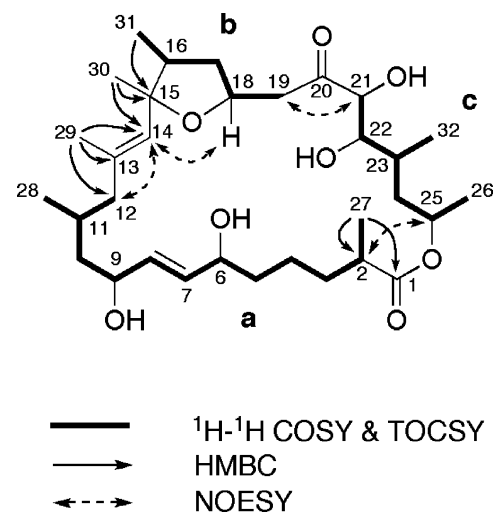

Fig. 1 Selected 2D NMR correlations for amphidinolactone B (1). 


Fig. 2 Selected NOESY correlations and relative
stereochemistry for tetrahydrofuran ring in
amphidinolactone B (1).

to $\mathrm{C}-14$ via $\mathrm{C}-13$ and $\mathrm{C}-13$ to $\mathrm{C}-29$ were implied by $\mathrm{HMBC}$ cross-peaks for $\mathrm{H}_{3}-29\left(\delta_{\mathrm{H}} 1.75\right)$ to $\mathrm{C}-12\left(\delta_{\mathrm{C}} 49.5\right), \mathrm{C}-13$ $\left(\delta_{\mathrm{C}} 137.5\right)$, and $\mathrm{C}-14\left(\delta_{\mathrm{C}} 131.9\right)$. Connectivities of C-14 to $\mathrm{C}-16$ via $\mathrm{C}-15$ and $\mathrm{C}-30$ to $\mathrm{C}-15$ were derived from $\mathrm{HMBC}$ cross-peaks for $\mathrm{H}_{3}-30\left(\delta_{\mathrm{H}} 1.12\right)$ to $\mathrm{C}-14$ and $\mathrm{C}-15\left(\delta_{\mathrm{C}}\right.$ 85.2), and $\mathrm{H}_{3}-31\left(\delta_{\mathrm{H}} 0.77\right)$ to $\mathrm{C}-15 .{ }^{1} \mathrm{H}$ and ${ }^{13} \mathrm{C}$ chemical shifts of C-25 $\left(\delta_{\mathrm{H}} 5.29 ; \delta_{\mathrm{C}} 68.3\right)$ indicated that C-25 was involved in an ester linkage with $\mathrm{C}-1$. The NOESY correlation for $\mathrm{H}-2 / \mathrm{H}-25$ also supported the connectivity of C-25 to C-2. The connectivity of C-19 to C-21 through a remaining keto carbonyl at $\mathrm{C}-20$ was deduced from the molecular formula of $\mathbf{1}$ and the NOESY correlation for $\mathrm{H}_{2-}$ 19/H-21. The ${ }^{1} \mathrm{H}$ and ${ }^{13} \mathrm{C}$ chemical shifts of $\mathrm{CH}_{2}-19$ and $\mathrm{CH}-21$ (Table 1) in $\mathbf{1}$ corresponded well to those of $\mathrm{CH}_{2}-19$ $\left(\delta_{\mathrm{H}} 2.87,2.78 ; \delta_{\mathrm{C}} 45.9\right)$ and $\mathrm{CH}-21\left(\delta_{\mathrm{H}} 4.33 ; \delta_{\mathrm{C}} 77.7\right)$ in amphidinolide $\mathrm{B}$ [7], supporting that 1 possessed the same partial structure for $\mathrm{C}-19 \sim \mathrm{C}-21$ including a ketone at C-20 as amphidinolide B. The presence of a tetrahydrofuran ring was deduced from deuterium-induced shift [8] of oxymethine carbons in the HSQC spectra of 1 measured in $\mathrm{C}_{6} \mathrm{D}_{6} / \mathrm{CD}_{3} \mathrm{OD}(95: 5)$ and $\mathrm{C}_{6} \mathrm{D}_{6} / \mathrm{CD}_{3} \mathrm{OH}(95: 5)$, respectively, as follows. Four oxymethine signals for C-6 $\left(\delta_{\mathrm{C}} 72.5\right), \mathrm{C}-9\left(\delta_{\mathrm{C}} 70.1\right), \mathrm{C}-21\left(\delta_{\mathrm{C}} 79.2\right)$, and $\mathrm{C}-22\left(\delta_{\mathrm{C}}\right.$ $75.2)$ showed significant deuterium-induced shifts, whereas two oxymethine signals for $\mathrm{C}-18\left(\delta_{\mathrm{C}} 74.3\right)$ and $\mathrm{C}-25 \mathrm{did}$ not show such deuterium-induced shift, implying that $\mathrm{C}-18$ was connected to $\mathrm{C}-15$ through an ether linkage, and that $\mathrm{C}-25$ was involved in an ester linkage with $\mathrm{C}-1$. The ${ }^{1} \mathrm{H}-{ }^{1} \mathrm{H}$ coupling $\left(J_{7,8}=15.4 \mathrm{~Hz}\right)$ of the disubstituted double bond at C-7 and C-8 indicated the $E$ geometry. The $E$ geometry of the double bond at $\mathrm{C}-13$ and $\mathrm{C}-14$ was deduced from the NOESY correlation observed for $\mathrm{H}-12 / \mathrm{H}-14$ as well as the ${ }^{13} \mathrm{C}$ chemical shift of $\mathrm{C}-29\left(\delta_{\mathrm{C}} 18.5\right)$. Thus, the gross structure of amphidinolactone $\mathrm{B}$ was elucidated to be $\mathbf{1}$.

The relative stereochemistry of C-15, C-16, and C-18 in the tetrahydrofuran ring was deduced from NOESY

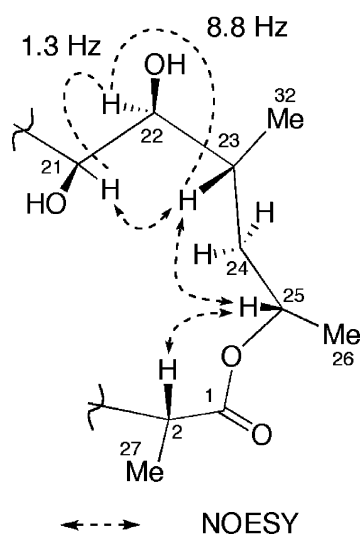

Fig. 3 Selected NOESY correlations and ${ }^{1} \mathrm{H}-{ }^{1} \mathrm{H}$ couplings and relative stereochemistries for amphidinolactone $B(\mathbf{1})$ (C-21 C-25 and C-1 C-2 moieties).

correlations as shown in Fig. 2. NOESY correlations for H14/H-18 implied that C-14 and H-18 were both $\alpha$-oriented, while NOESY correlations observed for $\mathrm{H}_{3}-30 / \mathrm{H}_{3}-31$ suggested that $\mathrm{C}-30$ and $\mathrm{C}-31$ were both $\beta$-oriented (Fig. 2).

The relative stereochemistry of C-2, C-22, C-23, and C25 was elucidated from ${ }^{1} \mathrm{H}-{ }^{1} \mathrm{H}$ couplings and NOESY correlations (Fig. 3). The values for ${ }^{3} J_{\mathrm{H}-21 / \mathrm{H}-22}(1.3 \mathrm{~Hz})$ and ${ }^{3} J_{\mathrm{H}-22 / \mathrm{H}-23}(8.8 \mathrm{~Hz})$ indicated a syn relationship for $\mathrm{H}-21$ and $\mathrm{H}-22$ and an anti relationship for $\mathrm{H}-22$ and $\mathrm{H}-23$, respectively. NOESY correlations of $\mathrm{H}-23 / \mathrm{H}-25$ and $\mathrm{H}-$ 25/H-2 suggested that $\mathrm{H}-2, \mathrm{H}-23$, and $\mathrm{H}-25$ were oriented toward the same direction. Furthermore, considering conformation of the macrocyclic ring, the relative stereochemistries of the $\mathrm{C}-21 \sim \mathrm{C}-25$ and $\mathrm{C}-1 \sim \mathrm{C}-2$ moieties were elucidated as shown in Fig. 3.

Since the carbon skeleton of $\mathbf{1}$ is the same as those of amphidinolide B-type macrolides [11], the stereochemistry of C-9 and C-11 in 1 may be the same as those of amphidinolide B-type macrolides. The stereochemistry of C-6 remains to be defined, due to a very limited amount of the sample $(80 \mu \mathrm{g})$.

1 is a new 26-membered macrolide possessing a tetrahydrofuran ring, a keto carbonyl, four hydroxyl groups, and six branched methyls. 1 showed cytotoxicity against L1210 murine leukemia cells and human epidermoid carcinoma $\mathrm{KB}$ cells $\left(\mathrm{IC}_{50}, 3.3\right.$ and $5.3 \mu \mathrm{g} / \mathrm{ml}$, respectively) in vitro.

Acknowledgment The authors thank Ms. S. Oka, Center for Instrumental Analysis, Hokkaido University, for measurements of ESI-MS. This work was partly supported by a Grant-in-Aid for Scientific Research from the Ministry of Education, Science, Sports and Culture of Japan. 


\section{References}

1. (a) Kobayashi J, Kubota T. Bioactive macrolides and polyketides from marine dinoflagellates of the genus Amphidinium. J Nat Prod 70: 451-460 (2007)

(b) Takahashi Y, Kubota T, Kobayashi J. Amphidinolactone A, a new 13-membered macrolide from dinoflagellate Amphidinium sp. Heterocycles 72: 567-572 (2007)

2. (a) Satake M, Murata M, Yasumoto T, Fujita T, Naoki H. Amphidinol, a polyhydroxypolyene antifungal agent with an unprecedented structure, from a marine dinoflagellate, Amphidinium klebsii. J Am Chem Soc 113: 9859-9861 (1991)

(b) Paul G. K, Matsumori N, Murata M, Tachibana $\mathrm{K}$. Isolation and chemical structure of amphidinol 2, a potent hemolytic compound from marine dinoflagellate Amphidinium klebsii. Tetrahedron Lett 36: 6279-6282 (1995)

3. Huang X, Zhao D, Guo Y, Wu H, Trivellone E, Cimino G. Lingshuiols A and B, two new polyhydroxy compounds from the Chinese marine dinoflagellate Amphidinium sp. Tetrahedron Lett 45: 5501-5504 (2004)

4. Washida K, Koyama T, Yamada K, Kita M, Uemura D.
Karatungiols A and B, two novel antimicrobial compounds, from the symbiotic marine Amphidinium sp. Tetrahedron Lett 47: 2521-2525 (2006)

5. Provasoli L. In: Culture and Collection of Algae. Watanabe A, Hattori A. (eds.) Japanese Society of Plant Physiology, Tokyo, pp. 63-75 (1968)

6. For detection of the keto carbonyl, treatment of 1 with 2,4dinitrophenylhydrazine gave the 2,4-dinitrophenylhydrazone; ESI-MS $m / z 745(\mathrm{M}-\mathrm{H})^{-}$; HRESI-MS ( $m / z 745.4028$ $\left[(\mathrm{M}-\mathrm{H})^{-}\right.$; calcd for $\left.\left.\mathrm{C}_{38} \mathrm{H}_{57} \mathrm{O}_{11} \mathrm{~N}_{4}, 745.4024\right]\right)$.

7. Ishibashi $M$, Ohizumi $Y$, Hamashima $M$, Nakamura $H$, Hirata Y, Sasaki T, Kobayashi J. Amphidinolide-B, a novel macrolide with potent antineoplastic activity from the marine dinoflagellate Amphidinium sp. J Cem Soc, Chem Commun: 1127-1129 (1987)

8. (a) Pfeffer PE, Valentine KM, Parrish W. Deuterium-induced differential isotope shift carbon-13 NMR. 1. Resonance reassignments of mono- and disaccharides. J Am Chem Soc 101: 1265-1274 (1979)

(b) Reuben J. Isotopic multiplets in the carbon-13 NMR spectra of polyols with partially deuterated hydroxyls. 4 . Molecular structure as reflected in the carbon-13 NMR spectra of oligosaccharides with partially deuterated hydroxyls. J Am Chem Soc 107: 1747-1755 (1985) 